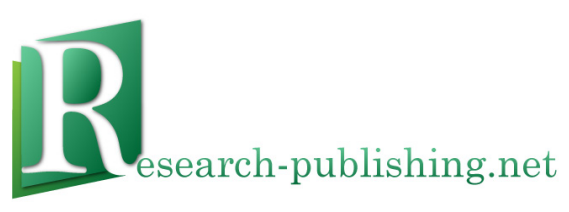

Published by Research-publishing.net

Dublin, Ireland; Voillans, France

info@research-publishing.net

(C) 2012 by Research-publishing.net

Research-publishing.net is a not-for-profit association

CALL: Using, Learning, Knowing

EUROCALL Conference, Gothenburg, Sweden

22-25 August 2012, Proceedings

Edited by Linda Bradley and Sylvie Thouësny

The moral right of the authors has been asserted

All articles in this book are licensed under a Creative Commons Attribution-Noncommercial-No Derivative Works 3.0 Unported License. You are free to share, copy, distribute and transmit the work under the following conditions:

- Attribution: You must attribute the work in the manner specified by the publisher.

- Noncommercial: You may not use this work for commercial purposes.

- No Derivative Works: You may not alter, transform, or build upon this work.

Research-publishing.net has no responsibility for the persistence or accuracy of URLs for external or thirdparty Internet websites referred to in this publication, and does not guarantee that any content on such websites is, or will remain, accurate or appropriate. Moreover, Research-publishing.net does not take any responsibility for the content of the pages written by the authors of this book. The authors have recognised that the work described was not published before (except in the form of an abstract or as part of a published lecture, or thesis), or that it is not under consideration for publication elsewhere. While the advice and information in this book are believed to be true and accurate on the date of its going to press, neither the authors, the editors, nor the publisher can accept any legal responsibility for any errors or omissions that may be made. The publisher makes no warranty, expressed or implied, with respect to the material contained herein.

Trademark notice: Product or corporate names may be trademarks or registered trademarks, and are used only for identification and explanation without intent to infringe.

How to access the book: http://research-publishing.net/publications/2012-eurocall-proceedings/

ISBN13: 978-1-908416-03-2 (paperback)

Print on demand (lulu.com)

British Library Cataloguing-in-Publication Data.

A cataloguing record for this book is available from the British Library.

Bibliothèque Nationale de France - Dépôt légal: décembre 2012. 


\title{
Collaborative Strategic Reading on Multi-Touch and Multi-User Digital Tabletop Displays
}

\author{
Jaber Ali Maslamani ${ }^{*}$, Scott Windeatt ${ }^{\mathrm{a}}$, Patrick Olivier ${ }^{\mathrm{b}}$, Phil Heslop ${ }^{\mathrm{b}}$, \\ Ahmed Kharrufa $^{\mathrm{b}}$, John Shearer ${ }^{\mathrm{b}}$, and Madeline Balaam ${ }^{\mathrm{b}}$
}

a. School of Education, Communication \& Language Sciences, Newcastle University, Newcastle upon Tyne, UK b. Culture Lab, School of Computing Science, Newcastle University, Newcastle upon Tyne, UK

\begin{abstract}
This paper is part of a work-in-progress that reports on the design, development, and evaluation of a Digital Collaborative Strategic Reading (DCSR) application with regard to its effectiveness in improving English as a second language (ESL) reading comprehension. The DCSR application allows users to read collaboratively on multitouch and multi-user digital tabletop displays that support both face-to-face and computerbased interaction. The application is designed to provide systematic instruction on tabletop computers using four main comprehension strategies that form the Collaborative Strategic Reading (CSR) instructional approach. The paper addresses one main research question: 'How does the use of the tabletop-based reading application (DCSR) affect learners' reading processes and outcomes?", and the following sub-questions: (1) What is the impact of the tabletop-based reading system on learners' reading scores with regard to the reading assessments? (2) How do learners collaboratively construct meaning on the tabletop? To answer these research questions, the subjects used the DCSR application on tabletop computers in groups of four, once a week for 5 weeks. Data were collected and analysed using both qualitative and quantitative methods. Each reading session was preceded by a cloze test and followed by two types of assessment: a written recall test and a cloze test; both tests were designed to reflect the students' comprehension of the reading passages. The paper will report on the design of the software and the administration of the study, but will focus on the analysis of the data from the different sources, and present insights into the nature of collaborative reading using the DCSR application on a tabletop computer.
\end{abstract}

Keywords: digital collaborative strategic reading, tabletop computing.

\section{Introduction}

The tabletop computer is an emerging technology which, with its large multi-touch surface that enables collocated synchronous collaboration, has clear potential for

\footnotetext{
* Contact author: jaber.maslamani@yahoo.com
} 
application in learning contexts. This paper will investigate the effectiveness of a tabletop-based computer application (Digital Collaborative Strategic Reading - Digital CSR or DCSR) as a collaborative reading instructional tool for enhancing the reading comprehension of English as a second language students.

International ESL students at tertiary level institutions in the UK and elsewhere need to reach a level of proficiency in English which will allow them to cope linguistically with their studies. Proficiency in reading is especially important for such students, as is effective instruction of L2 reading (e.g., Anderson, 1999; Huckin \& Bloch, 1993). They and other researchers argue that reading is probably the most important skill for L2 students in academic or learning contexts (Carrell, 1988; Fasheh, 1995; Hafiz \& Tudor, 1989; Pretorius, 2000, p. 35; Saville-Troike, 1984).

One particular approach to teaching reading - Collaborative Strategic Reading is based on the principles of reciprocal teaching (Palincsar \& Brown, 1984), which include a number of clearly specified procedures such as collaborative group work and interactive dialogue (Kim et al., 2006). CSR has potential benefits for the teaching and learning of reading as it is designed to offer instruction of explicit specific strategies and 'clearly specified procedures' for reading comprehension, which are practised through collaboration at all stages of the reading activity. Instruction of this kind has been associated with positive results in enhancing reading comprehension and avoiding text comprehension failure (Bremer, Vaughn, Clapper, \& Kim, 2002; Klingner \& Vaughn, 1998, 1999, 2000; Klingner, Vaughn, \& Schumm, 1998; Vaughn, Klingner, \& Bryant, 2001).

Collaboration among learners usually takes place around a table, and the "traditional table" is a tool that is well known for its axiomatic and intuitive support for small group collaboration; a familiar picture in educational settings. These features, as well as the rich experience that learners carry as a result of daily contact with tables in classrooms have motivated technologists to introduce interfaces for digital tabletops that share a lot of the interaction and communication features that are associated with work around "traditional tables" (Kharrufa, 2010; Kharrufa \& Olivier, 2010; Scott, Grant, \& Mandryk, 2003). As a result, the current study is concerned with the development and evaluation of an integrated application for teaching and practising reading on a tabletop computer that combines the strengths of "traditional table" collaboration with the collaborative features offered by digital tabletop computers.

\section{Method}

This project started by looking at specific requirements for designing applications for collaborative learning around digital tabletops. Studies of interaction design recommend starting with observation of how people apply their knowledge of the physical world and their everyday experience when using collaborative learning tools (e.g., Preece, Rogers, \& Sharp, 2002). In addition to design guidelines drawn from previous studies, 
most current tabletop-based systems are therefore based on "observational studies on the use of traditional tables" (Kharrufa, 2010, p. 7). Kharrufa and Olivier (2010), for example, developed design requirements based on a review of the relevant literature, and on their own observation of table-based collaboration, including the learners' use of gazing, body positions, and different tools while taking part in collaborative activities. Their observations confirmed the results of other similar studies regarding issues of territoriality on the tabletop surface, orientation of artefacts such as notes on the tabletop, use of gestures, and other aspects of collaboration.

The development of the DCSR application followed an iterative design approach that involved several stages, beginning with paper prototypes, followed by digital prototypes. The digital prototypes then underwent usability testing, with each digital prototype developed, evaluated in use, modified and re-evaluated. The design of the DCSR was based on the principles of the CSR approach, observation studies of paper CSR available in the literature and the most up-to-date studies on tabletop-assisted learning.

\subsection{DCSR implementation}

The paper addresses one main research question: 'How does the use of the tabletopbased reading application (DCSR) affect learners' reading processes and outcomes?', and the following sub-questions: (1) what is the impact of the tabletop-based reading system on learners' reading scores with regard to the reading assessments? and (2) how do learners collaboratively construct meaning on the tabletop computer? To answer these research questions, the subjects used the DCSR application on the tabletop computers in groups of four, once a week for 5 weeks. Five different reading texts of similar length and difficulty (intermediate level) were used; one reading text for every reading session. Each reading session started with previewing the whole text, followed by brainstorming then prediction of the content of the text. Then the learners read the text paragraph by paragraph to get the gist, dealing with unknown words, and then write down their understanding of each paragraph in digital notes. They conclude the task with a wrap-up stage in which they evaluate and monitor their understanding of the whole text by generating questions and answers. At the end of each of these stages they collaboratively organise their notes into groups based on similarities among the ideas. In order to assess reading comprehension, students take the same cloze test before and after the reading session and a written recall test after the session. Qualitative and quantitative methods are employed for both the data collection and the data analysis procedures.

\subsection{Preliminary results and analysis}

This work-in-progress is mainly qualitative, and the qualitative results form the core of the study. However, quantitative results can reflect a lot on students' achievement on the tabletop computer and about the impact of this technology on their performance. 
Based on a preliminary analysis of qualitative data, the grouping feature, a tool for allowing the learners to organise ideas, questions or problems about the text into groups, was helpful in making students' thinking visible to their peers, thus leading to incidents of comprehension check, and encouraging requests for further explanation and elaboration as well as corrective feedback. Grouping also encouraged problemsolving and planning (e.g., by organising notes into groups), both of which require reasoning and decision making. The orientation of digital notes (i.e., who was able to read an individual learner's notes as a result of the way he or she chose to orientate them on the tabletop) and the multi-keyboard-based input facility (i.e., each learner had a keyboard they could use) acted as non-verbal prompts for feedback from other peers or for further explanation. Test results have shown an improvement in students' scores in the cloze test between the pre-test and the post-test. There is also a positive correlation between their scores in the cloze post-test and the written recall test as both variables move in tandem.

\section{Discussion}

Preliminary findings suggest that tabletop computers and the DCSR application have potential benefits in language learning and more specifically in collaborative reading. Findings suggest that the grouping tool used each of the main reading strategies to have been tried once (brainstorming, prediction, get the gist, and wrap-up) and that it supports the externalisation of the students' thinking. During the grouping activity, students engage in organising note-slips into groups. They have already summarised ideas and written them inside digital notes to share with others during grouping. Organising the notes that contain similar ideas into groups requires planning, making decisions, and reasoning about which notes belong to which group and engages students in problem-solving throughout the whole process. The grouping tool and digital notes can also encourage scaffolding, allowing high-achievers to see others' notes on the tabletop surface and pinpoint areas of confusion that low-achievers may have, and to offer appropriate help (Pressley, Hogan, Wharton-McDonald, Mistretta, \& Ettenberger, 1996).

The orientation of objects on the tabletop was found to be a useful tool for comprehension as it allows for easier reading of the text, for communication with peers, and for coordination (see Kharrufa, 2010; Kharrufa \& Olivier, 2010). Other elements of effective collaboration such as space, students' behaviour and actions also affected the design of the application and students' construction of meaning while reading on tabletop computers, though consideration of these is beyond the scope of this paper.

\section{Conclusions}

The current exploratory study of the use of a Digital Collaborative Strategic Reading application contributes to understanding how tabletop computers can support co-located 
synchronous face-to-face collaborative reading and to investigating the impact of the tabletop-based computer application, DCSR, on ESL students' reading comprehension. There is evidence from a preliminary analysis of the data that learners coped well with the technology. Also, features of the DCSR software such as orientation and grouping of notes are associated both with interaction and collaboration, and with an improvement in reading comprehension and reading scores.

\section{References}

Anderson, N. J. (1999). Improving reading speed: activities for the classroom. English teaching forum, 37, 2-5.

Bremer, C. D., Vaughn, S., Clapper, A. T., \& Kim, A. (2002). Collaborative Strategic Reading (CSR): Improving secondary students' reading comprehension skills. Research to Practice Brief, 1(2). Retrieved from http://www.ncset.org/publications/viewdesc.asp?id=424

Carrell, P. L. (1988). SLA and classroom interaction: reading. Annual review of applied linguistics, 9, 223-242. doi: 10.1017/S026719050000091X

Fasheh, M. J. (1995). The reading campaign experience with Palestinian society: innovative strategies for learning and building community. Hardvard educational review, 65(1), 66-92.

Hafiz, F. M., \& Tudor, I. (1989). Extensive reading and the development of language skills. English language teaching journal, 43(1), 4-13. doi: 10.1093/elt/43.1.4

Huckin, T., \& Bloch, J. (1993). Strategies for inferring word meaning from context: A cognitive model: In T. Huckin, M. Haynes, \& J. Coady (Eds.), Second language reading and vocabulary learning (pp.153-178). Norwood, NJ: Ablex Publishing.

Kharrufa, A. S. (2010). Digital tabletops and collaborative learning. (Unpublished doctoral dissertation). Newcastle University, UK.

Kharrufa, A. S., \& Olivier, P. (2010). Exploring the requirements of tabletop interfaces for education. International Journal Learning Technology, 5(1), 42-62. doi: 10.1504/IJLT.2010.031615

Kim, A-H., Vaughn, S., Klingner, A., Woodruff, A. L., Reutebuch, C. K., \& Kouzekanani, K. (2006). Improving the reading comprehension of middle school students with disabilities through computer-assisted collaborative reading. Remedial and special education, 27(4), 235-249.

Klingner, J. K., \& Vaughn, S. (1998). Using Collaborative Strategic Reading. Retrieved from http:// www.Idonline.org/article/103

Klingner, J. K., \& Vaughn, S. (1999). Promoting reading comprehension, content learning, and English acquisition through collaborative strategic reading (CSR). The Reading Teacher, 52, 738-747.

Klingner, J. K., \& Vaughn, S. (2000). The helping behaviors of fifth-graders while using collaborative strategic reading during ESL content classes. TESOL Quarterly, 34(1), 69-98. doi: $10.2307 / 3588097$

Klingner, J. K., Vaughn, S., \& Schumm, J. S. (1998). Collaborative strategic reading during social studies in heterogeneous fourth-grade classrooms. The Elementary School Journal, 99(1), 3-22.

Palincsar, A. S., \& Brown, A. L. (1984). Reciprocal teaching of comprehension-fostering and comprehension-monitoring activities. Cognition and Instruction, 1(2), 117-175. doi: 10.1207/ s1532690xci0102_1 
Jaber Ali Maslamani, Scott Windeatt, Patrick Olivier, Phil Heslop, Ahmed Kharrufa, et al.

Preece, J., Rogers, Y., Sharp, H. (2002). Interaction Design, beyond human-computer interaction. New York: John Wiley and Sons, Inc.

Pressley, M., Hogan, K., Wharton-McDonald, R., Mistretta, J., \& Ettenberger, S. (1996). The challenges of instructional scaffolding: The challenges of instruction that supports student thinking. Learning Disabilities Research and Practice, 11, 138-146.

Pretorius, E. J. (2000). "What they can't read will heart them": reading and academic achievement. Innovation, 21, 33-41. Retrieved from http://www.innovation.ukzn.ac.za/InnovationPdfs/ No21pp33-41Pretorius.pdf

Saville-Troike, M. (1984). What really matters in second language learning for academic achievement? TESOL Quarterly, 18(2), 199-219. doi: 10.2307/3586690

Scott, S. D., Grant, K. D., \& Mandryk, R. L. (2003). System Guidelines for Co-located Collaborative Work on a Tabletop Display. Proceedings of ECSCW-3: European Conference on ComputerSupported Cooperative Work (pp. 159-178).

Vaughn, S., Klingner, J. K., \& Bryant, D. P. (2001). Collaborative Strategic Reading as a Means to Enhance Peer-Mediated Instruction for Reading Comprehension and Content-Area Learning. Remedial and Special Education, 22(2), 66-74. doi: 10.1177/074193250102200201 